\title{
Making Beverages Cherry Brewed Leaves (Muntigia calabura. 1) with Stevia (Stevia rebaudiana) as a Low- Calorie Natural Sweetener
}

\author{
Mulyati M. Tahir ${ }^{1, *}$, Mariyati Bilang ${ }^{1}$, Jumriah Langkong ${ }^{1}$, \\ Nurmitasari ${ }^{1}$, Anisyah Hariadi ${ }^{2}$ \\ ${ }^{1}$ Department of Agricultural Technology, Hasanuddin University, Makassar, Indonesia \\ ${ }^{2}$ Faculty of Medical, Bosowa University, Makassar, Indonesia \\ *Corresponding author. Email: p.mulyati@yahoo.com
}

\begin{abstract}
Drinks combination of cherry leaves and dried stevia leaves can be used as a health drink contains antioxidants and low-calorie sugar. This study aims to get types of proper drying in the manufacture of beverages so that the antioxidant content is not damaged and lost. The analysis was conducted on the analysis of sensory, physicochemical and microbiological testing. The design methods Completely Randomized Design (CRD) with 2 factorials. The first factor is the addition of stevia leaf dry consisting of 4 levels $(0 \%$, $25 \%, 50 \%$ and $75 \%$ ), the second factor is the type of drying which consists of two type of (drying by oven blowers and drying by oven vacuum), while the vacuum drying the best in terms of sensory analysis (color, aroma, and taste) and antioxidant activity of $77.8 \%$, brewed beverage formulations obtained by the treatment of dry cherry leaves $75 \%$ and $25 \%$ of dry stevia leaves with the results of sensory analysis (color, aroma and flavor) rather liking, the antioxidant activity of $78.5 \%$, and total calories of $2.9 \mathrm{kcal}$.
\end{abstract}

Keywords: cherry leaves, stevia, brewed beverages, low-calorie beverages, antioxidants

\section{INTRODUCTION}

Indonesia is a tropical country that is famous for its plant diversity which can be used as natural medicine. Plant parts that can be used as medicine in the form of leaves, stems, fruits, flowers and roots. One of the plants that can be used as natural medicine is cherry. According to Peruvian folklore, cherry leaves can be boiled or soaked in water, to reduce swelling of the prostate gland, as a medicine to reduce heat, eliminate headaches, flu and treat gout, but also can be used as an antiseptic, antioxidant, antimicrobial, anti-inflammatory (reduce inflammation), antidiabetic, and antitumor. Through this approach, it can be said that the cherry leaves contained antioxidant compounds can be used as an anti-diabetes and can inhibit the activity of bacteria that cause disease because it is thought to contain flavonoid compounds. Flavonoids are the largest group of natural phenol compounds and are polar compounds because they have a number of hydroxyl groups, so they will dissolve in polar solvents such as ethanol and methanol. Flavonoids are active compounds that can be used as antioxidants, antibacterial, and antiinflammatory because they can inhibit the activity of bacteria that cause disease. The physicochemical test results of the methanol extract of cherry leaves are known to contain secondary metabolites of flavonoid, triterpenoid, tannin, saponin and steroid classes.
Sweetened processed foods, industrial products, as well as drinks and health foods are often added. Sweeteners function to improve taste, and aroma, improve physical and chemical properties, as preservatives, develop types of drinks and foods with a controlled number of calories. Stevia leaf itself is widely used as a natural sweetener for diabetics or even for those on a diet program. Because stevia has a sweet taste on the tongue without producing extra calories for the body compared to other sweeteners, this is because stevia leaves contain glycosides consisting of two components namely stevioside (3-10\% dry weight of leaves) and rebaudioside (1-3\%) which has 250-400 times the sweetness of sucrose, which is stable at $100 \mathrm{oC}$, $\mathrm{pH}$ range 3-9 and does not cause dark colors when cooking. Stevia also contains protein, fiber, carbohydrates, phosphorus, potassium magnesium, sodium, iron, vitamin $\mathrm{A}$, vitamin $\mathrm{C}$ and also oil.

The form of serving by brewing is an alternative in order to get the efficacy of cherry leaves easily and does not require a long time when you want to be consumed, other than that the method and procedure is not difficult, namely by pouring hot water on dried cherry leaves and stevia leaves, then stirring it then filtered and ready for consumption. Based on the statement above that cherry leaves contain flavonoid compounds and stevia leaves which have a sweet taste and low in calories and the consumption process does not require a long time when made into a powder that is ready to be brewed, then in this study the process of 
making brew drinks, with basic ingredients dried cherry leaves and the addition of dried stevia leaves as a natural sweetener. The purpose of this research is to find out the drying process of cherry leaves so that the antioxidant activity of cherry leaves is not lost during the drying process and to find out the right mixing formulation between cherry leaves and stevia leaves for making brew drinks..

\section{METHODS}

\section{Material}

The materials used in this study were cherry leaves (Muntigia Calabura. L) obtained in Makassar South Sulawesi, dried stevia leaves (stevia Rebaudiana Bertoni M) imported from the Yogyakarta Special Region, 1,1diphenyl-2-pikril-hydrazine (DPPH), methanol, pH 7 buffer solution, alcohol, PCA media, $\mathrm{NaCl}$, Aquades, tissue, mineral water, and aluminum foil.

\section{Tool}

The tools used in this research are digital scales, measuring cups, volume pipes, bulp, Erlenmeyer, spoons, grinders, vacuum ovens, oven blowers, containers, porcelain cups, petri dishes, reaction tubes, vortex, bunsen, decoders, $\mathrm{pH}$ meters, and glass bottles.

\section{Research Procedure}

First pick and pick the leaves that are not too old or too young, which is $10 \mathrm{~cm}$ from the top of the tree. Then weighed and washed 200 grams and lysed for 10-16 hours kept at room temperature and dark place and then dried for two treatments using a vacuum oven and using an oven blower at $60 \mathrm{oC}$ and at the same time for 2 days, then weighed again, then polished using grinder tools then weighed. Then add dried stevia leaves by $0 \%, 25 \%, 50 \%$ and $70 \%$. Then, it was boiled in $300 \mathrm{ml}$ of boiling mineral water for each sample.

\section{Research Treatment}

The treatment in this study used a two factorial randomized block design. The first factor is the percentage of stevia leaf addition in brewed drinks. The second factor is the type of dryer on cherry leaves.

The percentage factor of the addition of stevia leaves to the cherry leaf brewing drinks consists of 4 levels viz :

\section{A0 : $100 \%$ cherry leaf}

A1 : $75 \%$ cherry leaf $+25 \%$ dried stevia leaves

A2 : $50 \%$ cherry leaf $+50 \%$ dried stevia leaves

A $3: 25 \%$ cherry leaf $+75 \%$ dried stevia leaves

Factors of the type of dryer used in making brew drinks are :

B1: Oven Blower Dryer

B2: Vacuum Oven Dryer

\section{Antioxidant Activity DPPH Method}

Samples were weighed as much as $0.1 \mathrm{~g}$, added / dissolved into methanol $98 \%$ as much as $5 \mathrm{ml}$, Divortex to homogeneous, centrifuged at $4000 \mathrm{rpm}$ for 10 minutes,
Taken $4 \mathrm{ml}$ of supernatant as much as $4 \mathrm{ml}$ then added DPPH $0.2 \mathrm{mM}$ as much as $1 \mathrm{ml}$, Silent in a dark place for 30 minutes, measured $517 \mathrm{Nm}$ wavelength absorbance. Calculated (\%) inhibition;

$\mathrm{A}=$ Absorbance blank - Absorbance sample/ Absorbance blank x 100\%

Water rate (zhou., et al [6])

Measurement of sample water content is carried out by a drying process. The working procedure for measuring water content is as follows; The empty cup and lid are dried in the oven for 15 minutes. Rapidly weighed about 5 grams of the sample that has been homogenized in a saucer. Samples are put in a saucer and put in an oven for 3 hours. The cup cools 3-5 minutes. After chilling the ingredients are weighed. The material is dried again in the oven for 30 minutes until a constant or constant weight is obtained. Moisture content is calculated by the formula;

$\%$ Water rate $=$ beginning-to-end weight/end-weight $\times 100 \%$

PH value (Sudarmadji dkk, [11])

The $\mathrm{pH}$ measurement is done by using a $\mathrm{pH}$ meter and then taking about $50 \mathrm{ml}$ of sample filtrate and stirring it evenly. The $\mathrm{pH}$ meter is turned on and the $\mathrm{pH}$ electrode is washed with distilled water and then wiped using blotting paper. The $\mathrm{pH}$ measurement is carried out by inserting the electrodes in the material that has been homogenized, then the results will be immediately known by reading the numbers indicated by the instrument. Every time the $\mathrm{pH}$ meter is used, the electrodes are cleaned as in the initial measurement.

\section{Microbial / TPC Total Analysis (Fardiaz [9])}

Weighed the material as much as 1 gram then put it in a test tube containing $9 \mathrm{ml}$ of distilled water so that a 10-1 dilution was obtained. Pipette suspension as much as $1 \mathrm{ml}$ and then put into a test tube containing $9 \mathrm{ml}$ of $10-2$ dilution aquades. Done continuously until reaching dilutions $10-5$ and 10-6. Then $1 \mathrm{ml}$ pipette from dilution 10-6 into a petri dish then poured PCA media (Plate Count Agar) and then incubated for 48 hours. Observed microorganisms that grow then calculated by the formula :

Number of mircrobes $=$

$$
\text { (total colony) } /([(1 \mathrm{xn})+(0,1 \mathrm{xn})+(\ldots) \mathrm{d}\})
$$

Calorie Value with Bomb calorimeter (wijanarko, 2013).

Calories can be calculated using a device called a calorimeter bomb. The calorie calculation method is done by inserting a dry sample into a platinum dish, then the sample in the platinum dish is put into a "bomb" then closed and the lid tightened. After that the bomb is filled with $\mathrm{O} 2$ until the pressure reaches $25 \mathrm{~atm}$. Then the bomb is put into calorimetry filled with water. Furthermore, the flow of electricity is delivered to a wire so that the combustion occurs as seen from the temperature rise. Furthermore, it can be seen the number of calories contained in the sample. 


\section{Design Model}

This research was conducted with a randomized block design (RBD) consisting of 2 factorials with 2 replications where factor A addition of stevia leaves and factor B was the type of drying used and then the data was processed in variance analysis. If the results are significantly different, it will be carried out with the Duncan test as a follow-up test.

\section{RESULTS AND DISCUSSION}

\section{Water Rate}

Analysis of water content needs to be done to determine the water content owned by brewing drinks because the water content in food ingredients determines acceptability, freshness, and durability of the material itself.

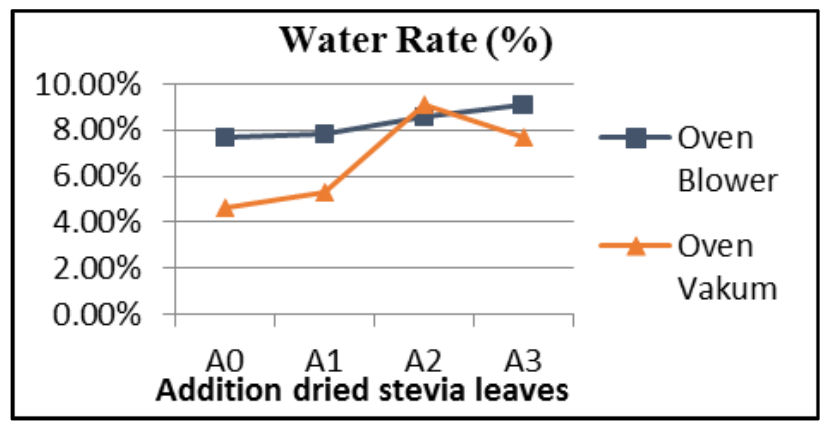

Figure 1. Relationship between the addition of stevia leaves and type of drying to the percentage of brewed water content.

The addition of stevia leaves affects the percentage of brewed water content analysis. This is due to the addition of stevia leaves and the same cherry leaf which is $50 \%$ cherry leaf and $50 \%$ stevia leaves so that it makes the water content increase when two ingredients are mixed with the same amount the percentage of water content increases. This is in accordance with Kurniawan, I. Sarwiyono and Surjowardojo [4] and D. Chattopadhya, 2007 [1] that in 100 grams of cherry leaf has a water content of $77.8 \%$ and dried stevia leaves in 100 grams have a water content of $7 \%$. The results of the water content obtained do not exceed the standards set by SNI for Black Tea Bags which have been set to a maximum of $10 \%$, so it is expected that the product's durability will be longer.

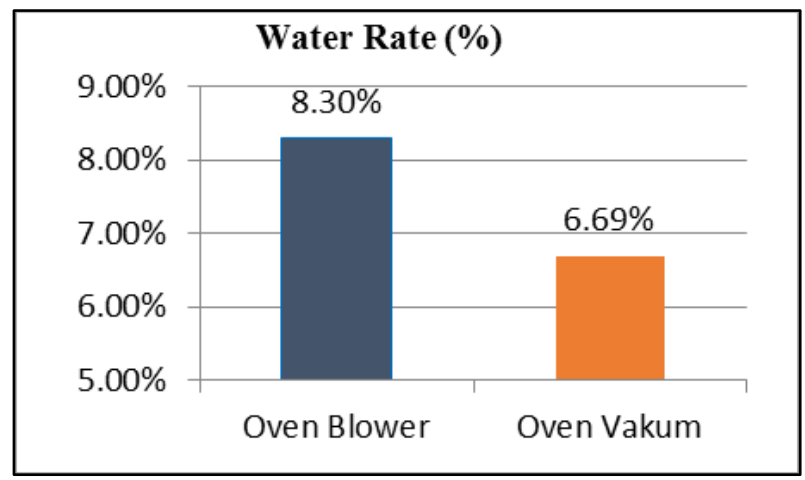

Figure 2. The relationship between types of drying to the percentage of brewed water content.
The type of drying affects the analysis of the percentage of brewed water content. This is because drying using a blower oven has the principle of convection where heat transfer is accompanied by intermediaries while drying using a vacuum oven has a conduction principle that is the transfer of heat energy is not followed by the intermediates. So that the drying in the blower oven is less than optimal for removing water from the cherry leaf compared to a vacuum oven. This is in accordance with the statement Estiasih [8] and Geankoplis [10] that the working principle of the oven blower dryer in general is heating the material by using the principle of heat transfer by convection while the vacuum drying of heat transferred in general by conduction.

Duncan further test results showed that the addition of stevia leaves $0 \%$ was not significantly different from the addition of $25 \%$ stevia leaves, but both were significantly different from the treatment of adding $50 \%$ and $75 \%$ stevia leaves (appendix 2b). The duncan further test results for the type of oven blower drying are significantly different from vacuum oven drying (appendix 2c).

\section{Acidity level ( $p H)$}

Results of analysis of variance states that the addition of stevia leaves has a very significant effect on the analysis of the acidity of brewing drinks as well as the type of drying which has a very significant effect on the analysis of acidity, while the interaction of the two has a significant effect on the analysis of acidity (appendix 03).

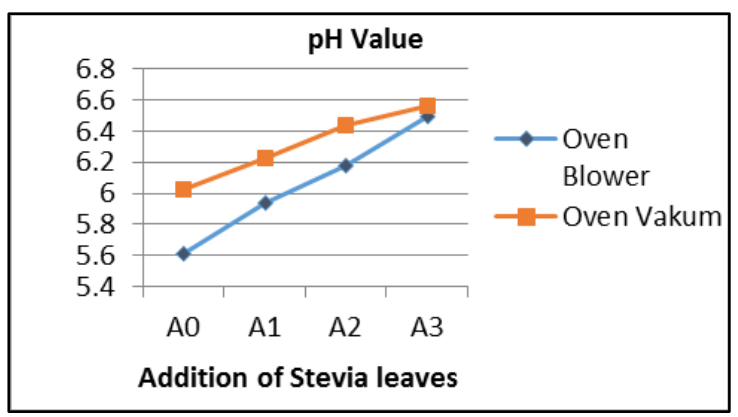

Figure 3. Relationship between the addition of stevia leaves and the type of drying to the $\mathrm{pH}$ of brewed drinks.

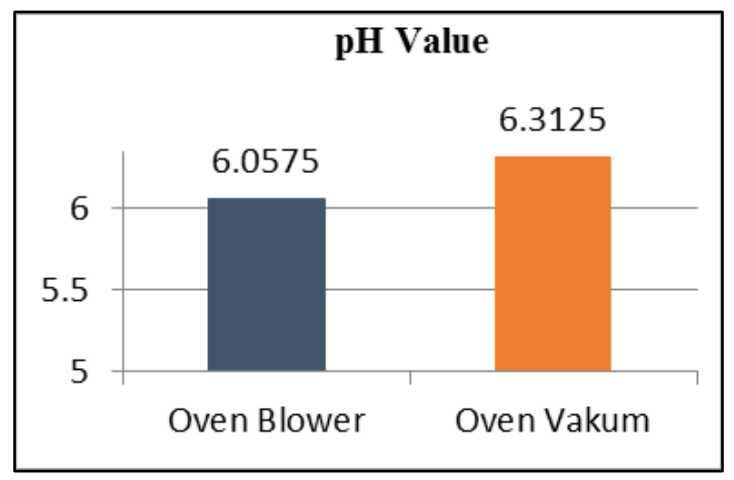

Figure 4. Relationship between Dryer Type and pH of brewed drinks.

The addition of stevia leaves affects the $\mathrm{pH}$ value of brewed drinks, this is due to the tannin content of stevia 
leaves, this is in accordance with the statement Ibrahim Ghazi, Bayu Wicaksono, Abdullah [3] that the properties of tannins in water are colloidal and weak acids so that tannins are headed towards neutral.

This type of drying affects the $\mathrm{pH}$ value of brewed drinks, this happens because the lower the water content of an ingredient, the $\mathrm{pH}$ will increase as it is known that the vacuum oven dryer has an average value of water content lower than the oven blower dryer type, this is appropriate. with deMan, John M. [7] which states that the water content is low then the $\mathrm{pH}$ will be greater than 6 .

The results of duncan further tests showed the effect of adding stevia leaves to the $\mathrm{pH}$ value of the addition of stevia leaves $0 \%$ significantly different from the addition of stevia leaves $25 \%$, significantly different from the addition of stevia leaves $75 \%$ and also significantly different from the addition of stevia leaves $50 \%$ (appendix $4 \mathrm{~b}$ ). Whereas the type of drying oven blower is significantly different from the type of drying oven vacuum (attachment 4c).

\section{Antioxidant Activity}

Antioxidants are chemical compounds that can contribute one or more electrons to free radicals, so that free radicals can be suppressed. One test to determine the antioxidant activity of radical scavengers is the DPPH method $(1,1$ Diphenyl-2-picrylhidrazyl). The DPPH method is a simple method developed to determine the antioxidant activity of a food substance using DPPH radicals.

The results of analysis of variance on antioxidant activity in making brewed drinks with the addition of stevia leaves had a very significant effect, the type of drying had a significant effect, while the interaction of both had a very significant effect on antioxidant activity (appendix 6a), so it was continued with further testing of the duncan method.

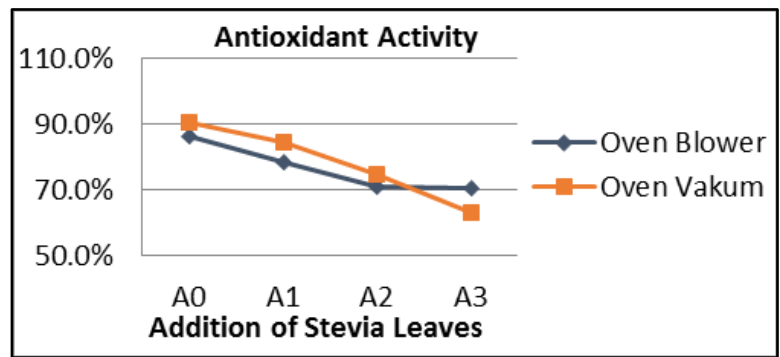

Figure 5. The relationship between the addition of stevia leaves and the type of drying to the antioxidant activity of brewing drinks.

The addition of stevia leaves affects the percentage of antioxidant activity of brewing drinks, this is because cherry leaf has a fairly high antioxidant compound than stevia leaves so that if the addition of stevia leaves is more than the cherry leaf, the content contained in cherry leaf is reduced. This is consistent with the statement of Triwaningsih [5] that the highest antioxidant compounds such as flavonoids and saponins are found in the leaves of cherry plants.

The type of drying also influences the percentage of antioxidant activity, namely the vacuum oven dryer has a higher percentage of antioxidant activity compared to the oven blower dryer. Vacuum oven dryers produce $78 \%$ while blower oven dryers produce $77 \%$. Brewed drinks produced by using a vacuum oven dryer are better because the drying process using a vacuum oven the material is not oxidized and the milard reaction can be controlled. This is in accordance with Geankoplis [10] another advantage of drying using a vacuum oven of non-oxidized products, the millard reaction can be controlled and can dry quickly.

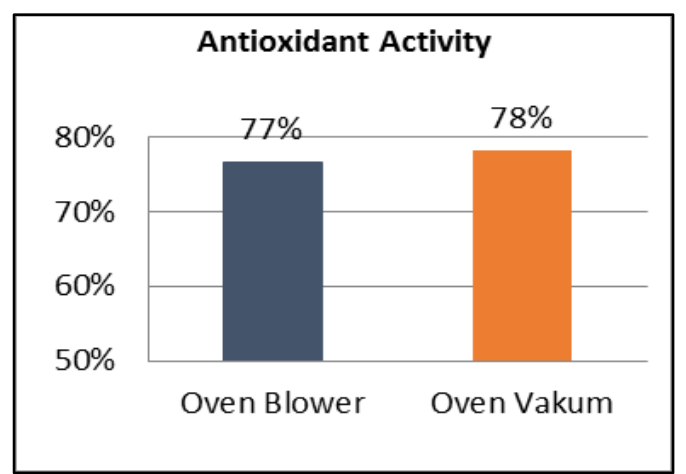

Figure 6. Relationship between Dryer Types and Antioxidant activities of brewing drinks.

The duncan test results show the effect of adding stevia leaves to antioxidant activity in the treatment of $100 \%$ cherry leaf significantly different from adding stevia leaves $25 \%$, significantly different from adding stevia leaves $75 \%$ and also significantly different from adding stevia leaves $50 \%$ (appendix 6b). As for the type of drying oven the blower is significantly different from the drying of the vacuum oven (attachment 6c).

\section{Calorie Total}

The results of testing the total calories of brewed drinks are as follows :

Table 1. Total calorie test analysis :

\begin{tabular}{|c|c|c|}
\hline Dryng type (B) & $\begin{array}{c}\text { Addition of stevia } \\
\text { leaves (A) }\end{array}$ & $\begin{array}{c}\text { Total } \\
\text { (Kkal/gram) }\end{array}$ \\
\hline \multirow{4}{*}{ B1 } & A0 & 3,618 \\
\cline { 2 - 3 } & A1 & 2,956 \\
\cline { 2 - 3 } & A2 & 3,643 \\
\cline { 2 - 3 } & A3 & 3,798 \\
\hline \multirow{4}{*}{ B2 } & A0 & 3,383 \\
\cline { 2 - 3 } & A1 & 2,911 \\
\cline { 2 - 3 } & A2 & 3,681 \\
\cline { 2 - 3 } & A3 & 3,897 \\
\hline
\end{tabular}

The total calorie yield is around $2.00-3.00 \mathrm{kcal} / \mathrm{g}$. The total calorie yield of A1 treatment was lower, $2.9 \mathrm{kcal} / \mathrm{g}$ compared to treatments $\mathrm{A} 0, \mathrm{~A} 2, \mathrm{~A} 3$, which reached 3.8, this was because not only stevia leaf calories contained in the brewed cherry leaf caloric value also existed. Obtaining a total calorie that is close to the calorific value of $2.7 \mathrm{kcal} /$ g stevia leaves, namely treatment (A1) $25 \%$ addition of stevia leaves, $2.9 \mathrm{kcal} / \mathrm{g}$. This drink is still said to be low in calories because it cannot meet the daily calorie needs, 
even though each individual has different caloric needs. However, the Indonesian Ministry of Health in general sets an individual calorie requirement of $2000 \mathrm{kcal} /$ day. As it is known that there is steviosida contained in stevia leaves which causes low calories produced in this study, this is because steviosida is a non-carbohydrate glycoside compound that has a sweet taste but produces low calories. This is consistent with the statement Donna G. [12] that stevioside in stevia is a non-carbohydrate glycoside compound. This compound is not owned by sucrose. Stevia also has several different properties with sucrose, namely a long storage life, stable to high temperatures, nonfermenting, but contains near-zero calories.

\section{Organoleptic}

\section{Total Microbes}

The total yield of brewed microbial drinks is as follows :

Table 2. Calculation of total microbial colonies

\begin{tabular}{|c|c|c|}
\hline \multirow{2}{*}{ Dried type (B) } & $\begin{array}{c}\text { Addition of } \\
\text { stevia leaves (A) }\end{array}$ & $\begin{array}{c}\text { Reporting } \\
\text { Results } \\
\text { (Log } \boldsymbol{c f u} / \mathbf{m l})\end{array}$ \\
\hline \multirow{4}{*}{ B1 } & $\mathrm{A} 0$ & $5,1 \times 10^{5}$ \\
\cline { 2 - 3 } & $\mathrm{A} 1$ & $5,5 \times 10^{5}$ \\
\cline { 2 - 3 } & $\mathrm{A} 2$ & $6,7 \times 10^{6}$ \\
\cline { 2 - 3 } & $\mathrm{A} 3$ & $5,9 \times 10^{5}$ \\
\hline \multirow{3}{*}{$\mathrm{B} 2$} & $\mathrm{~A} 0$ & 0 \\
\cline { 2 - 3 } & $\mathrm{A} 1$ & $6,9 \times 10^{6}$ \\
\cline { 2 - 3 } & $\mathrm{A} 2$ & $5,6 \times 10^{5}$ \\
\cline { 2 - 3 } & $\mathrm{A} 3$ & $5,7 \times 10^{5}$ \\
\hline
\end{tabular}

Source: Primary Data Research Results, 2015

The total microbes according to SNI (19-2897-1992) and the limit requirements for microbial contamination (SII 0154-90) The maximum ALT for brewing drinks is 1x106 colonies / $\mathrm{ml}$ or $6.00 \mathrm{log} \mathrm{cfu} / \mathrm{ml}$. This shows that the treatment of adding stevia leaves $0 \%, 25 \%, 50 \%$ with the type of drying oven blower and adding stevia leaves $0 \%$, $50 \%$, and $75 \%$ with the type of drying using a vacuum oven cherry leaf brewing can be consumed because it is still in SNI limit (19-2897-1992), whereas in the treatment of stevia leaf addition $50 \%$ with the type of drying oven blower and $25 \%$ with the type of drying oven vacuum passes the total microbes determined by SNI. This is due to factors after climate, environmental, humidity and so on so that after brewing there are still contaminated samples. This is accordance with Greenwalt CJ, Steinkraus KH, Ledford RA. [2], brewed tea consists of several microorganisms such as bacteria and yeast. This is due to various factors such as climate, environment, humidity and so on.

\section{CONCLUSION}

Based on the results obtained it can be concluded that the drying type of cherry leaf using a vacuum oven is better because it can maintain the antioxidant content of cherry leaf, so that a high percentage of antioxidant activity is obtained, which is $78 \%$ per 1 gram of sample and the best formulation obtained is $75 \%$ dried cherry leaf $+25 \%$ dried stevia leaves.

\section{REFERENCES}

Journals

[1] Chattopadhya D., 2007. Stevia: Prospect as an Emerging Natural Sweetner. Veena Sharma .International Food Division, India.

[2] Greenwalt CJ, Steinkraus KH, Ledford RA. 2000. Kombucha, the fermented tea: microbiology, composition, and claimed health effects. J Food Protect 63:976-81.

[3] Ibrahim Ghazi, Bayu Wicaksono, Abdullah., 2013. Penghilangan Warna Coklat Larutan Gula Stevia Menggunakan Karbon Aktif. Jurnal Teknologi Kimia dan Industri, Vol. 2, No. 4,, Tahun 2013, Halaman 198-204. Online di: http:/lejournals1.undip.ac.id/index.php/jtki

[4] Kurniawan, I., Sarwiyono dan Surjowardojo, P. 2013. Pengaruh Teat Dipping Menggunakan Dekok Cherry leaf (Muntingia calabura L.) Terhadap Tingkat Kejadian Mastitis. Program Studi Produksi Peternakan. Fakultas Peternakan. Universitas Brawijaya. Malang.

[5] Triswaningsih D., Kumalaningsih S., Wignyanto., and Pratikto. 2017. Identification of chemical compounds cherry leaves ( Muntingia calabura) powder as a natural antioxidant. International Journal of Agronomy and Agricultural Research. 10(5): 84-91.

[6] Zhou Z.,Cai X., Cao W., Li X., and Xiong C. 2016. Influence of Water Content on Mechanical Properties of Rock in Both Saturation and Drying Processes. Rock Mech Rock Eng. 49:3009-3025.

$\underline{\text { Books }}$

[7] deMan, John M. 1997. Kimia makanan ; Edisi kedua.Alih bahasa : Kosasih Padmawinata. Bandung : ITB.

[8] Estiasih, Teti dan Ahmadi. 2009. Teknologi Pengolahan Pangan. PT Bumi Aksara. Jakarta.

[9] Fardiaz. 1993. Penuntun Praktikum Mikrobiologi Pangan. Jurusan Teknologi Pangan dan gizi, FAPERTA, IPB, Bogor.

[10] Geankoplis, C.J. 1983. Transport Process and Unit Operation. Third Edition. New Delhi: Prentice-Hall of India.

[11]Sudarmadji. 1997. Analisa Bahan Makanan dan Pertanian. Liberty Yogyakarta, Yogyakarta.

$\underline{\text { Internet }}$

[12] Donna G. 2000. A Tale and Incredible Sweetness and Intrigue, terdapat di dalam http://www.stevia.net/history.htm, diakses November 2015. 